Apidologie, 1980, 11 (3), 203-208.

\title{
STUDIES ON \\ THE PHYSICAL CHARACTERISTICS OF ARTIFICIAL PROTEIN DIETS FOR HONEYBEES (APIS MELLIFERA L.) I.
}

\author{
Keith M. DOULL (1), T. W. HANCOCK (2), and L. N. STANDIFER (3)
}

\section{SUMM ARY}

The effects of different sugars and mixtures of sugars on the consistency and rate of hardening of an artificial protein diet for honeybees have been examined. When a commercial High Fructose Corn Syrup provided the carbohydrate component, both mean consistency and rate of hardening of the diet were signigicantly higher than those for diets containing honey, laevulose or a $1: 1$ dextrose : laevulose mixture. The premature hardening of the corn syrup diet was shown to be due to an excess of dextrose over laevulose in the syrup.

\section{INTRODUCTION}

Artificial protein diets containing a commercial High Fructose Corn Syrup tended to harden more quickly than did similar diets in which honey provided the sugar component. The corn syrup diets could eventually become too hard for the bees to eat (Doull, 1977). This effect of the corn syrup on the consistencies of artificial protein diets was thought to be due to an excess of dextrose over laevulose in the syrup.

This is the first of two papers that present the results of studies on some factors affecting the consistency and hence the acceptability of artificial protein diets for honeybees.

(1) (2) Honorary Visiting Research Fellow, Entomology, and Statistical Consultant respectively, Waite Agricultural Research Institute, The University of Adelaide, Glen Osmond, South Australia 5064.

(3) Centre Director/Research Leader, U.S.D.A. Carl Hayden Bee Research Centre, Tucson, Arizona U.S.A. 
lines were then compared to the common regression line to establish the significances of differences in mean consistency and rates of hardening of the four diets.

Results of these analysis are presented in Table 1 which shows mean consistencies and regression co-efficients for Diets 1-4 in the two treatments.

Mean consistencies and regression co-efficients for the four diets, in both treatments were significantly different. However, the corn syrup diet was clearly the main cause of this significance with values for the other three diets being comparatively similar with regression co-efficients for Diet 4 being the lowest in both treatments.

A similar analysis was made of the effects of covering the diets. Results of this analysis are presented in Table 2 which shows levels of significance of differences between treatments in mean consistency and regression co-efficients.

Covering led to significant reductions in both the mean conistency and rate of hardening of the diet containing corn syrup. The mean consistencies of the laevulose and dextrose : laevulose diets were also significantly reduced when the diets were covered, but covering did not affect significantly rate of change in consistency of these diets. Diets containing honey were not significantly affected by covering either in consistency or rate of hardening.

\section{DISCUSSION}

The results of the experiment support the initial observation that an artificial protein diet containing H.F. Corn Syrup hardened more quickly than did a similar diet in which honey provided the carbohydrate component.

The beneficial effects of covering the diets to protect them from the evaporating power of the warm, comparatively dry air of the test room are also demonstrated. Covering the diets decreased the mean consistency and rate of hardening.

While some of these results did not reach statistical significance, their conformity with one another suggested that, had the experiment been carried out over a longer period, covering would have been shown to have a significant effect on the rates of hardening of all the diets.

The results also support the proposition that the premature hardening of the corn syrup diet resulted from the excess of dextrose over laevulose in the syrup.

The effects of variations in the dextrose : laevulose ration are shown in Table 3 which presents mean daily increases in consistency in relation to the $\mathrm{d}: 1$ ratios in the five diets tested. 

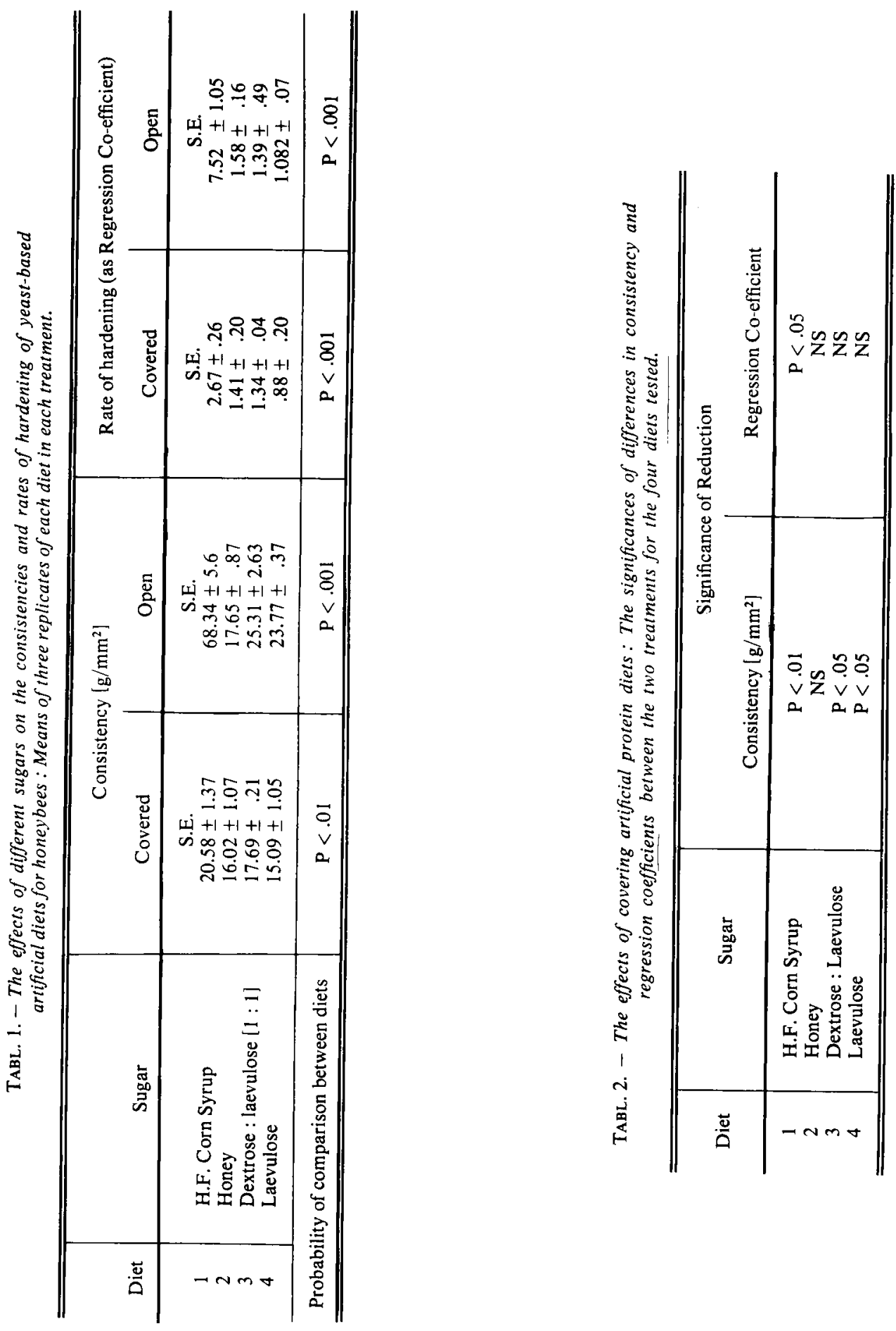
TABL. 3. - The effects of the dextrose: laevulose on the rates of hardening of yeast-based artificial protein diets for honeybees.

Daily increases in consistency of the five diets in the covered treatment.

(1) Fifteen days only. All other diets 17 days.

(2) From White (1978).

\begin{tabular}{c|l|c|c}
\hline \multicolumn{1}{|c|}{ Sugar } & D : L Ratio (\%) & $\begin{array}{c}\text { Increase in Mean } \\
\text { Consistency }\left(\mathrm{g} / \mathrm{mm}^{2} / \mathrm{day}\right)\end{array}$ \\
\hline 5 & Dextrose & $100: 0$ & $32.9(1)$ \\
1 & H.F. Corn Syrup & $50: 42$ & 2.35 \\
3 & Dextrose : Laevulose & $50: 50$ & 1.33 \\
2 & Honey (2) & $31: 38$ & 1.30 \\
4 & Laevulose & 0.100 & .75 \\
\hline \hline
\end{tabular}

The daily increase in consistency of the corn syrup diet was markedly greater than that of diets 2,3 and 4. There was a close similarity between diets 2 and 3 in which the $\mathrm{d}: 1$ ratios were $1: 1$ and $3.1 .: 3.8$ respectively, but when laevulose was the only sugar in the diet, the daily increase in consistency was substantially lower than that for all other diets.

In both the corn syrup and dextrose diets the increase in conistency was due to crystallization of the dextrose. A crust formed at the surfaces of all diets and in the corn syrup and dextrose diets this was hard and crystalline. In the dextrose diet the hardness of the crust exceeded the limits of the Penetrometer after the eighth day and as the depth of the crust increased so did the hardness of the body of the sample.

In the other diets a thin tough skin formed at the surface of the samples in both treatments. This did not increase substantially in thickness but as the experiment proceeded became more difficult to penetrate. A similar thin, shiny skin forms on the surface of honey exposed to the air and on the surface of pollen stored in the combs and presumably results from the formation of the fine crystals of laevulose. It would serve to reduce the rate of loss of water from stored pollen.

The performance of the diet containing the H.F. Corn Syrup was improved if the diets were covered but overall the results of this experiment suggest that the corn syrup is not the ideal syrup to use in the formulation of artificial protein diets.

A second paper will consider alternatives to corn syrup and honey and will discuss the significance of physical characteristics as they affect the acceptability of artificial protein diets for honeybees.

Received for publication in April 1980.

\author{
RÉSUMÉ \\ LES CARACTÉRISTIQUES PHYSIQUES \\ DES RÉGIMES PROTÉINIQUES ARTIFICIELS \\ POUR LES ABEILLES. I.
}

Dans le premier des 2 articles on discute des effets des différents sucres sur la consistance et le taux de durcissement du régime protéinique artificiel. La levure de bière séchée était la source protéinique de tous 
les régimes et l'expérience était destinée à tester une observation selon laquelle les régimes protéiniques artificiels, dans lesquels la composante glucidique est fournie par un sirop commercial de maïs à haute dose en fructose, durcissaient plus vite qu'un régime renfermant du miel.

Le test a été réalisé à $34,5^{\circ} \mathrm{C}$ et $55 \%$ d'humidité relative pour simuler les conditions qui règnent dans le nid à couvain d'une ruche en plein soleil en été. On a mesuré 8 fois les consistances des régimes sur une période de 17 jours à l'aide d'un pénétromètre qui mesure en $\mathrm{g} / \mathrm{mm}^{2}$ la force nécessaire pour pénétrer l'échantillon.

L'expérience a confirmé l'observation, puisque la consistance aussi bien que le taux de durcissement du régime au sirop de maïs étaient significativement plus élevés que ceux du régime au miel.

Dans les autres régimes on a montré que cet effet du sirop de maïs était dû à un excès de glucose par rapport au fructose dans le sirop.

Les résultats de l'expérimentation ont montré également que les régimes artificiels durcissaient plus lentement s'ils étaient enveloppés dans du papier enduit de cire pour les protéger contre la puissance d'évaporation de l'air chaud et sec.

Un second article exposera les résultats des tests avec d'autres sucres et d'autres levures et discutera de l'importance de la consistance et des taux de durcissement pour l'acceptation par les abeilles du régime artificiel.

\title{
ZUSAMMENFASSUNG
}

\author{
DIE PHYSIKALISCHEN EIGENSCHAFTEN \\ VON KÜNSTLICHER PROTEINNAHRUNG \\ FÜR HONIGBIENEN. I.
}

In der ersten von zwei Arbeiten werden die Einflüsse verschiedener Zucker auf die Konsistenz und auf den Anteil des Hartwerdens von künstlicher Proteinnahrung diskutiert. Im Sprühverfahren getrocknete Brauhefe bildete den Proteinanteil bei allen Futtergemischen; der Versuch wurde zur Prüfung einer Beobachtung durchgeführt, da künstliche Proteinpräparate, denen als Zucker ein kommerziell erzeugter "Stark-Fruktose-Mais-Syrup" zugesetzt war, rascher hart wurde als ein Präparat das Honig enthielt.

Die Versuche wurden bei $34,5^{\circ} \mathrm{C}$ und $55 \%$ relativer Feuchte durchgeführt, um die Bedingungen zu simulieren, die im Brutnest eines im Sommer in voller Sonne stehenden Bienenstockes herrschen. Die Konsistenz des Futtergemisches wurde in einem Zeitraum von 17 Tagen achtmal mittels eines Panetrometers gemessen; dabei wird die Kraft in $\mathrm{g} / \mathrm{mm}^{2}$ gemessen, die benötigt wird, um in das Muster einzudringen.

Der Versuch bestätigte die ursprüngliche Beobachtung, da beides, die mittlere Konsistenz und der Anteil des Hartwerdens beim Futter aus Maissirup signifikant höher war als bei Honigdiät. Bei anderen Futtermischungen konnte nachgewiesen werden, dass dieser Effekt des Maissirup auf ein Überwiegen des Dextrose-Anteils über den Laevulosegehalt im Sirup zurückzuführen war.

Die Ergebnisse des Versuchs haben ferner gezeigt, dass die künstlichen Futtermischungen langsamer hart wurden, wenn man sie in Wachspapier einhüllte, um sie vor dem Austrocknen in der warmen, relativ trockenen Umgebungstemperatur zu schützen.

Eine zweite Arbeit wird die Ergebnisse von Versuchen mit anderen Zuckern und Hefen darlegen und die Bedeutung der Konsistenz und des Anteils von hart gewordenem Futter für die Aufnahme der künstlichen Mischung durch die Bienen diskutieren.

\section{REFERENCES}

Budel A. and Herold, E. (1960). - "Biene und Bienenzucht ". Ehrenwirth Verlag, Munich.

Doull K. M. (1977). - Tucson Pollen Supplements. Am. Bee J. 117 (5) : 296-297.

Parker R. L. (1926). - The Collection and Utilization of Pollen by the Honeybee. Cornell Uni. Agr. Exp. Sta. Memoir No. 98.

White J. G. (1978). - In * The Hive and the Honeybee ». Dadant Co. Hamilton, Illinois, U.S.A. 